\title{
Editorial Principle of the Asian Journal for Public Opinion Research
}

\author{
Takashi Inoguchi, Editor-in-Chief \\ Professor Emeritus, University of Tokyo \\ President, University of Niigata Prefecture
}

Representing the Asian Network for Public Opinion Research (ANPOR), I would like to make brief remarks on the publication of the Asian Journal for Public Opinion Research (AJPor). It has been launched by a bunch of those academic and practitioners interested in conducting and analyzing public opinion in Asia. Asia has been one of the most diverse and dynamic, and uncertain and underrecognized areas of the world in the dawn of the 21st century. To navigate over terra incognita and undercognita, you need maps portraying those minds and hearts of those peoples residing in Asia. Public opinion survey and analysis are one of the instruments to understand those ordinary peoples have in mind experiencing joy and sorrow, pleasure and pain, amity and enmity. Public opinion has been widely recognized as one component of deepening democracy since the mid-last century. In conveying messages of people in emotive and rational expressions, public opinion research is indispensable to democracy. In making transparent about public policy and government conducts, public opinion research is also indispensable to democracy. Public opinion research enables democracy to articulate and aggregate the vox populi. In a similar vein, public opinion research is indispensable to globalized business. Public opinion research starts with human beings who live their lives as an individual, a person who has distinguishing sentiments and views about daily lives and beyond. Representing the nation by national averages is over. Ever changing and ever complex phenomena have been subjects and targets of public opinion research. The Asian Network for Public Opinion Research and its journal, the Asian Journal for Public Opinion Research are two forms of our expression that to understand better what people have in mind public opinion survey and analysis must be promoted and that a distinctive journal of their own making must excel itself amidst the ever globalizing world. 


\section{Biographical Note}

Takashi Inoguchi is Professor Emeritus, University of Tokyo and President, University of Niigata Prefecture. He is also former Assistant Secretary General of the United Nations assigned to The United Nations University Headquarters. He has B.A. and M.A. degrees from University of Tokyo and a Ph.D. from MIT. He has published numerous books and articles on a broad range of subjects. For the last decade he has executed large scale random sampled nation-wide surveys in all the Asian countries and societies (i.e., in East, Southeast, South and Central Asia, except for the Democratic People's Republic of Korea and Timor Leste) focusing on quality of life and well-being with 60 thousand respondents and 6 million observations. From this AsiaBarometer project he has published with co-author Seiji Fujii, The Quality of Life in Asia: A Comparison of Quality of Life in 29 Asian Countries and Societies (Springer, 2012). With Doh Chull Shin, coedited The Quality of Life in Asia (Springer 2010), coedited with Miguel Basanez et al, Values and Lifestyle in Urban Asia (SigloXXI Editores, 2005), and other there volumes of the AsiaBarometer (Akashi Shoten, 2001, 2008, 2009). On Japan and international affairs, he has published, among others, The Political Economy of Japan (Stanford University Press, 1988, coedited with Daniel Okimoto), American Democracy Promotion (Oxford University Press, 2000, coedited with Michael Cox and G. John Ikenberry), Japanese Politics Today (Palgrave Macmillan, 2011), and The U.S.Japan Security Alliance (Palgrave Macmillan, 2011). Dr. Inoguchi is a member of the Science Council of Japan, Founding Editor of Japanese Journal of Political Science (Cambridge University Press) and Journal of International Relations of the Asia Pacific (Oxford University Press). Of late, he is editor of Asian Journal of Political Opinion Research (open access journal). He also is Director of the AsiaBarometer Project and is Chairman of the Asian Consortium for Political Research. Based on Google Scholar Impact Indices, his total citations count (up to November 11, 2013) is 2,164; his h-index is 24, and his i10 index is 59 . He can be reached at inoguchi@ioc.u-tokyo.ac.jp. 